\title{
Building an Entrepreneurial Spirit Based on Model, Brain Color and Myers Briggs Type Indicator (MBTI)
}

\author{
${ }^{1}$ Endang Naryono \\ ${ }^{1}$ STIE PASIM, Sukabumi, West Java, Indonesia \\ *Corresponding author email: endang@ @stiepasim.ac.id
}

\begin{abstract}
Abstrac
One of the characteristics of an entrepreneur is that his thoughts and insights are oriented towards Action rather than just dreaming, wishing and talking. An entrepreneur always faces risk with uncertainty and limitations in every problem he faces. If we only speak words and do not take action, all opportunities that exist will turn into disasters and calamities in our lives. A drafter or theorist, works with data and is rarely in the field. On the other hand, an entrepreneur spends $95 \%$ of his time in the field with his employees, suppliers and customers. Because working with data, in order to be valid and scientific, a drafter must be accustomed to testing the data, building a model and doing validation. What will be a problem if a drafter does not master the situation and information in the field and can become doubtful about his decision so that he tends to repeat the cycle again. Namely collecting data that causes him to be spindly and more oriented to the mind than Action. On the other hand, an Action-oriented person is a person who has a high level of effectiveness. To study the characteristics of an Action-oriented person using the model of an effective person
\end{abstract}

Keyword : Charateristics, Enterpreneur, Action-oriented person using the model

\section{Introduction}

One of the characteristics of an entrepreneur lies in his thoughts and insights which are oriented towards Action rather than just dreaming, wishing and discourse. An entrepreneur always faces risk with uncertainty and limitations in every problem he faces. If we only speak words and do not take action, all opportunities that exist will turn into disasters and calamities in our lives.

An entrepreneur must have a PDCA orientation, namely plan, do, check, and action, this means not only planning various strategies and tactics but by implementing them. Specifically, an entrepreneur should avoid NATO (no action talk only), NADO (no action dream only) and NACO (no action concept only) NATO will only produce gossip, NADO will only produce a vision without Action, NACO will only produce theory and philosophy. In general, those who think NACO are academics who think using formal logic. NACO's way of thinking is as follows:

A drafter or theorist, works with data and is rarely in the field. On the other hand, an entrepreneur spends $95 \%$ of his time in the field with his employees, suppliers and customers. Because working with data, in order to be valid and scientific, a drafter must be accustomed to testing the data, building a model and doing validation. What will be a problem if a drafter does not master the situation and information in the field and can become doubtful about his decision so that he tends to repeat the cycle again. Namely collecting data that causes him to be spindly and more oriented to the mind than Action.

On the other hand, an Action-oriented person is a person who has a high level of effectiveness. To study the characteristics of an action-oriented person using the model of an effective person as proposed by Stephen Covey (2004) which includes:

According to Stephen Covey, an effective human being is a human being based on fair attitudes, prioritizing togetherness, having integrity, being honest, dignified, and balanced, willing to serve. Patient, diligent, caring and determined and always think positively. These values are very important because they will make us more confident in acting. People who have no integrity, are less fair and dishonest tend to be emotionally unstable and their lives are not peaceful. He can have a company but it's hard to make it big. Resault. 


\section{Literature Review}

In addition, Covey argues that a person's character is determined by a habit, therefore habits that must be developed by an entrepreneur are habits that are productive. Specifically, the eight habits are be proactive, begin with the end in mind, put first think first, thing win/win. See first to understand-then to be understood, synegrgize, sharvepen the saw, they find their voice and help other fine their (Covey, 2004)

1. Proactive

2. Starting from the tip of the mind

3. Prioritizing the same thing

4. Think and Act

5. Seek first to understand then to be understood

6. Synergy

7. Sharpen Resilience, Flexibility and Strength

8. Discovering personal uniqueness and helping others

The eighth habit is closely related to changing from effective behavior to extraordinary for that, a person must start by discovering or recognizing his uniqueness. Find his uniqueness. Finding uniqueness means knowing your potential which is spread over the four main elements, namely mind, body, heart and soul. If the mind is continuously developed and a great vision can be formulated. Then it can strengthen a person and develop the greatest potential of a person, institution or company, that is the lantern of the soul.

Like Bo Peabody, people use sociopaths, namely people who recognize that they are unique and different from the average person. According to him, ordinary people do not want a job that is not clear. They just want a normal job. Bo Peadbody approached them and realized that they had the capabilities he wanted and needed them as employees (Peadbody, 2002).

\section{Result}

\subsection{Personal test : Brain Color}

The way we think will determine what kind of action will be taken every time we are faced with a problem, everyone has a different color of mind. How do you think about how you respond to problems, let's take the following test:

This test is brain color. Pay attention to the statements in the following questionnaire, and please take a writing utensil and give a score of your choice.

You are asked to give a score between 1 to 4 on each line of the words below. In the statements below, you will find words that you usually encounter. Some words you like more than others because they represent you better. Then give a score of 4 on the word that represents you and 1 which does not represent you. While the words that are close to yourself give a score of 3 or 2

Note, the filling must be line by line (Horizontal) open vertically, you may move to the next line when one line has been completed. After you've finished adding up the scores for each column and the score terms at the bottom, now circle the high total scores. Your lecturer will explain what the color of your thinking program is. Reflect and think about how to change if you are not happy with the color of your mind.

Note: Contemplation $=$ Contemplative, need time to think, contemplating is not spontaneous.

Source: Glazov, S.N., 2007. What color is Your Braind? A Fun And Fascinating Aproach To Understanding Yourself And Other. Thorofare: Slank Inc.

Brain Color Questionnaire

1. Fill in line by line, not vertically, remember after one line is complete you can move to the next line.

2. In each row there should not be the same score so there should be a score of 1, 2, 3 and 4 depending on your respective assessment of yourself. Please give a clear, clear answer honestly

\begin{tabular}{|l|l|}
\hline \multicolumn{2}{|l|}{ Give a Rating About Yourself } \\
\hline 4 & $:$ I totally agree (Strongly Agree) \\
\hline 3 & $:$ Approaching \\
\hline 2 & $:$ Slightly Less \\
\hline 1 & $:$ Rarely / Not me at all (Strongly disagree \\
\hline
\end{tabular}




\begin{tabular}{|c|c|c|c|c|c|c|c|}
\hline \multicolumn{2}{|r|}{ A } & \multicolumn{2}{|r|}{ B } & \multicolumn{2}{|r|}{ C } & \multicolumn{2}{|r|}{$D$} \\
\hline$\ldots$. & Organized & $\ldots$ & Creative & $\ldots$ & Independent & $\ldots$ & Enthusiastic \\
\hline$\ldots$. & On time & $\ldots$. & Communicative & $\ldots$ & Curiosity & $\ldots$. & Enjoyment \\
\hline$\ldots$. & Details & $\ldots$ & Flexible & $\ldots$. & Be patient & $\ldots$. & Competitive \\
\hline$\ldots$. & Responsible & $\ldots$. & Attention & $\ldots$. & Analytical & $\ldots$ & Long Mind \\
\hline$\ldots$. & Committed & $\ldots$ & sensitive & $\ldots$. & Takafur & $\ldots$ & Brave \\
\hline$\ldots$. & $\begin{array}{l}\text { Caution can be } \\
\text { accounted for }\end{array}$ & $\ldots$ & Cooperative & $\ldots$ & Technical & $\ldots$ & Energetic \\
\hline$\ldots$. & Respect & $\ldots$. & Original & $\ldots$. & Competence & $\ldots$. & Generous \\
\hline$\ldots$. & Predictable & $\ldots$ & nurturing & $\ldots$. & Investigative & $\ldots$. & Spontaneous \\
\hline \multicolumn{8}{|c|}{ When making decisions, I tend to: } \\
\hline$\ldots$. & Talk with & $\ldots$ & \multicolumn{3}{|c|}{ Summing up the facts } & $\ldots$ & Have a Planning \\
\hline$\ldots$. & Another & $\ldots$ & Fact & $\ldots$. & Trust instinct & & \\
\hline \multicolumn{8}{|c|}{ When working with others, I see myself as: } \\
\hline$\ldots$. & Coaches & $\ldots$. & Team player & $\ldots$. & Problem Solvers & $\ldots$. & Troubleshooter \\
\hline \multicolumn{8}{|c|}{ I feel comfortable in a work environment that: } \\
\hline$\ldots$ & Stable/quiet & $\ldots$. & Harmonious & $\ldots$. & Privacy & $\ldots$. & Free \\
\hline .... & A Total & $\ldots$. & B Total & $\ldots$. & C Total & $\ldots$. & D Total \\
\hline
\end{tabular}

Calculate your total score, the highest score A means that you belong to type A, if your score is the most B, then you belong to type B, and so on.

Question :

1. What color is most suitable for being an entrepreneur?

2. Can you change it?

\subsection{Myers Briggs Type Indicator (MBTI)}

Glasov (2008) describes his findings as a derivative of the MBTI concept, only making it simpler and easier to implement. MBTI on the other hand is a very powerful psychological measurement tool that is widely used everywhere to measure human personality. In the field of Human Resources management, MBTI is widely used in the recruitment of new employees, placement of executives (promotions) and so on.

developed by Myers and Briggs until Isabel Myers died in 1980 and then continued by the Foundation founded by Myers and psychologist Mars McCoulley who continues to do psychological research.

According to MBTI, there are 4 things that distinguish the human personality that causes one person to be fast, others so slow to make decisions more than others and so on. These four things are as follows:

1. Source of Energy (Extraversion or Intraversion)

This concerns the issue of decision-making energy. There are people who rely heavily on energy sources that come from outside themselves (exstraversion) and rely heavily on themselves (introversion), namely through their own contemplated concepts. Very often found there who like to get along, a lot of consultation or dissolve with large groups. More action oriented than competing and being alone in a closed space with few people or limited circles.

2. Information Process (Sensing or Intuition)

Some people sniff information through sensing, while others rely on intuition. They are called first "as it is" (as it is) by relying on facts that are caught by the ears, nose, skin and tongue. Thus they can be very down to earth relying on what was at the time. While the second type is more oriented towards interpretation or applying or meaning from what he saw from before. Thus he can be more visionary or idealistic, more interested in the future

3. Decision Making (Thingking or Feeling)

Decision making (judgment) carried out by humans also varies, some rely heavily on thought/logic (non-personal object, analytical) and some use feelings (subjective, personal prudence). The first (Thingking) are people who are very rational and ignore emotions so as if they are considered more scientific and objective, intellectual and smarter. Yet they are merely thinking clearly, one-sidedly, based on facts. While the second (feeling) is most likely to really consider the relationship (harmony) or cooperation so be careful 
4. Running Life (Judgement or Perceiving)

There are people who prefer things to be organized, organized, with a planned list and expect others to do the same (judgment). Meanwhile, there are people who like to organize their lives and lead with a perceiving approach, namely responding to something relaxed, spontaneous, no need to be organized, waiting for the right moment and placing more emphasis on experience than order.
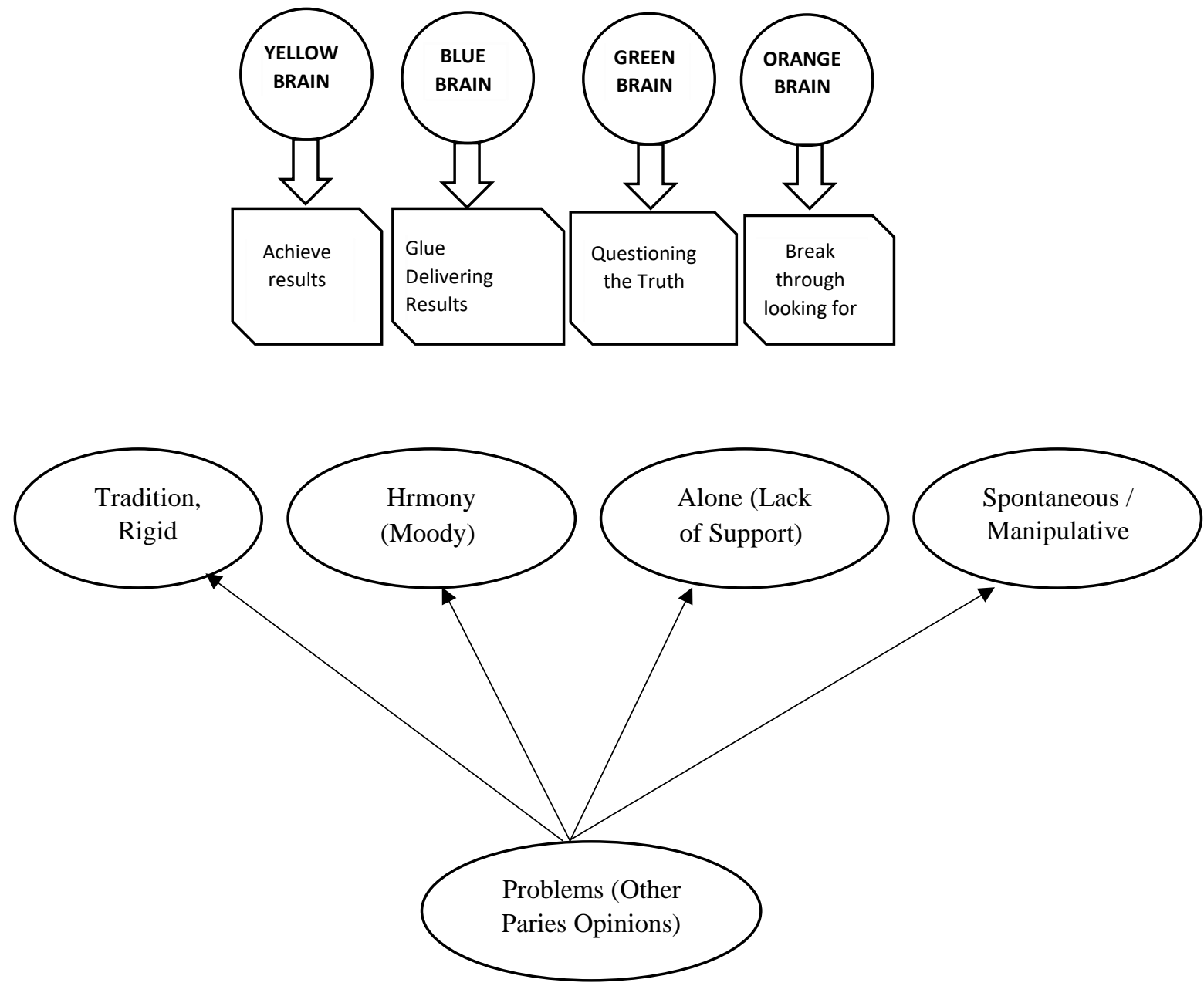

In acting, each color owner has a unique way of thinking. The owners of orange brains tend to live independently, free from shackles and have no doubts. But he is often considered manipulative, unstable and adventurous by owners of other colors. Whereas in a crisis, the orange is needed because they are innovative and have a lot of sense.

The owners of green brains are critical and logical but are not supported by many people who cannot cooperate with others and when opposed are less flexible in responding to problems, if they do not get support. While the owner of a blue brain that has the potential to glue people together and likes to help others. Often less sharp and moody. Meanwhile, yellow brain owners who usually work systematically are less able to think paradoxically and are still trapped by stable and traditional ways of working so that in some respects they are seen as rigid and less flexible people.

So everyone has abilities and problems that can become determinants and obstacles in penetrating the crisis. In fact, the hope of leading in that situation can be assigned to the orange brain. But he needs support, cooperation, and trust from the people around him of different colors.

Unfortunately, every color has a preference for the same color as them, so the owners of the yellow brain believe that great and good people are those who work in a systematic, procedural, detailed, organized and responsible manner like them. Likewise, the owner of a green brain thinks in this world the great people are those with green brains and so on. So it's really hard for them to support different colors 


\section{Conclution}

1. Know your brain color and identify its advantages and disadvantages

2. Also recognize the brain color of your teammates or business partners and employees

3. Conduct a workshop to overcome the brain color of all team members so that each team member is no longer a single dominant color, but becomes multicolor. The more colorful the better for overcoming the crisis

4. Give the trust to develop a business to a leader who has an orange brain or a yellow brain or has a combination of these two colors (multicolor)

\section{References}

Dareck, Carol.2006. Change Your Mindset Your Life. Jakarta : Serambi

Gladwell, M. 2008. Outliers: Story of Success. New York : Litle Brown and Companny

Hassobah, Z.I. 2004. Developing Creative and Cretical Thingking Skill. Bandung : Nuansa

Harrington, Scott E., dan Gregor R. Niehaus. 2004. Risk Management and Isurance. 2 nd Ed.NY : McGraw

Koestenbaum, P. 2002. Leadership : The Inner Side of Greatness : A Philosophy For Leader : San Francisco : Josssey-Bass

Kyosaki, R.T. 2002. Guide to Investing. Jakarta : Gramedia Lum.Michael.2008.NLP Scret. Jakarta: Mitra Media

Maxwll, J.C. 2007. Tallen is Never Enough: Discover The Choices That Will Take You Beyond Your Tallen. California : Thomas Nelson, Inc Maxwell, J.C. 2002. Leadership 101 : What every Leader Need ti Know. Tennessee: Thomas Nelson, Inc.

Naryono, E. 2020. Pedoman Penulisan Skripsi Program Sarjana. Sukabumi : P3M STIE PASIM

Naryono, E. 2020. Strategi Pemasaran. Sukabumi : P3M STIE PASIM

Overton, R.2002. Improve Your Management Skill. Warton Book

Sherwood. 2006. Innovation and Creativity. Jakarta : Elex Media Word book, 2008.

The Word book Encyclopedia. Chicago : World Book, Inc 